\title{
Wastewater Effluents at Sierra Leone Bottling Company Limited: Composition, Assessment and Removal Efficiency of Physico-chemical Parameters
}

\author{
Joe Milton Beah ${ }^{1}$, Abass Thullah ${ }^{1}$, Alfred Abu ${ }^{2}$, Daniel Kaitibi ${ }^{2}$, Abu Bakarr Sheriff ${ }^{3}$, \\ Eldred Tunde Taylor, ${ }^{1, *}$ \\ ${ }^{1}$ Institute of Environmental Management and Quality Control, School of Environmental Sciences, Njala University, Main Campus, Njala, \\ Sierra Leone \\ ${ }^{2}$ Department of Physics and Computer Science, School of Technology, Njala University, Main Campus, Njala, Sierra Leone \\ ${ }^{3}$ Institute of Languages and Cultural Studies, School of Education, Njala University, Towama, Sierra Leone
}

\section{Email address:}

Joe_beah@yahoo.co.uk(J. M. Beah), abassmeeshee@yahoo.com (A. Thullah), aabu@njala.edu.sl (A. Abu), dkaitibi@njala.edu.sl (D. Kaitibi), absheriff@njala.edu.sl (A. B. Sheriff), etaylor@njala.edu.sl (E. T. Taylor)

${ }^{*}$ Corresponding author

\section{To cite this article:}

Joe Milton Beah, Abass Thullah, Alfred Abu, Daniel Kaitibi, Abu Bakarr Sheriff, Eldred Tunde Taylor. Wastewater Effluents at Sierra Leone Bottling Company Limited: Composition, Assessment and Removal Efficiency of Physico-chemical Parameters. Journal of Water Resources and Ocean Science. Vol. 6, No. 3, 2017, pp. 46-50. doi: 10.11648/j.wros.20170603.11

Received: April 20, 2017; Accepted: May 2, 2017; Published: June 7, 2017

\begin{abstract}
The analyses of industrial effluents at Sierra Leone Bottling Company Limited (SLBC) in Freetown, the capital city of Sierra Leone were conducted to assess its composition, and removal efficiency of physico-chemical parameters. Fifteen (15) samples were collected from the drain water (influent), pre treatment effluent and treated effluent (effluent) for five days. There were significantly higher concentrations of influents parameters relative to those of the corresponding effluents. The influent levels for $\mathrm{pH}$, electrical conductivity and chloride were higher than permissible threshold. $80 \%$ of the samples at the influent point were within permissible guideline for TDS but all were in total agreement with the effluent samples for the same parameter. Comparative analyses showed significant reduction in values for $\mathrm{pH}$, temperature, iron and chromium in the effluent samples relative to the influent samples and all of the other parameters did not show any statistically significant differences. The treatment plant was noted to be highly efficient in removing iron and chromium but least efficient for total dissolved solids and water temperature. Huge variances with respect to removing contaminants for chloride, electrical conductivity and total dissolved solids were observed. The average overall removal efficiency of contaminants in industrial effluents was low but the practice of treating industrial wastewater by SLBC was plausible. Considering the pollution load of certain parameters being investigated, it is imperative for the SLBC to initiate the process of setting up waste stabilization ponds (WSP) so as to contain industrial effluents for further examination before they are discharged into the environment.
\end{abstract}

Keywords: Industrial Effluent, Wastewater, Physico-Chemical Parameter, Removal Efficiency, Sierra Leone

\section{Introduction}

There is a direct proportionality between increasing urbanization or industrialization and the rate of water pollution. In beverage industries, water is the key processing medium and it is used throughout the stages of mineral production which includes drink production, sweetening and coloring processes, cleaning and washing of bottles, plant wash down. This consequently increases the demand of water usage and ultimate discharge of wastewater whether treated or untreated into the environment. Effluents from industries are discharged into water bodies such as, rivers, lakes, streams etc, and such a practice has significant implications for aquatic ecosystem. Wastewater composition varies from the type of industry or manufacturing process (es) that is involved. For instance, high electrical conductivity was observed in a beverage industry in Pakistan [1] but high 
content of biological oxygen demand (BOD) and chemical oxygen demand (COD) are characteristic of diary wastewater [2]. The problem of effective treatment of wastewater is more acute in underdeveloped or developing countries due to the high cost of conventional treatment systems [3] and such untreated or poorly treated wastewater eventually find its way to agricultural farm lands which have deleterious longterm effects on soil, groundwater and human health [4].

Several studies have looked wastewater characteristics in other countries [5-7] and others have investigated removal efficiency of wastewater indicators $[8,9]$ while another study assessed the possibility of reuse of wastewater [2] and two other studies have looked at removing heavy metals from industrial effluents $[10,11]$. However, one that has evaluated the composition and removal efficiency of wastewater indicators in Sierra Leone is unavailable. The Environment Protection Agency Sierra Leone (EPA-SL) has put in place policies for effective conservation and management of natural resources. This is against the backdrop that there is unsustainable and wasteful utilization of resources (water). Despite the gains made by EPASL over the years in managing our ever dwindling resources, challenges are still apparent due to the insufficient mobilization of resources. Given the lack of empirical data on the quality of effluent discharged into water bodies in Sierra Leone, there was the need to assess the composition and removal efficiency of selected physico chemical indicators contained in effluents released by Sierra Leone Bottling Company Limited (SLBC) which is one of the very few companies in Sierra Leone with waste water treatment plant. Information obtained from this study would guide decision makers in their discharge of policies geared towards protecting the health, resources and livelihood options for the local population.

\section{Materials and Method}

The Sierra Leone Bottling Company Limited (SLBC) formally known as Freetown Cold Storage Company Limited is located at George Brook Dworzark Farm in Freetown, the capital city of Sierra Leone. It lies along latitude $8^{\circ} 29^{\prime} 2.39^{\prime \prime}$ $\mathrm{N}$ and longitude $13^{\circ} 14^{\prime} 2.40^{\prime}$ ' W. Dworzark is located along the mountainous terrain west of the city which is approximately $1.5 \mathrm{~km}$ from city center via Pademba Road. The SLBC is situated on a piece of land with a total area of $23,945 \mathrm{~m}^{2}$ and the facility is positioned about $15 \mathrm{~m}$ from the George Brook on the west bank of the stream that runs across the company perimeter. The company in recent years has embarked on standard best practices by installing state of the art equipments in rebranding the company's image. CocaCola products such as Coco-cola, Vimto and Parrot beverages are produced and package in $300 \mathrm{ml}$ bottles and PET plastic bottles. Because of its significance, the company is one of the biggest companies in Sierra Leone with significant prospect of growth.

Samples were collected from three locations or points; point one (the drain of the washer and production referred to as influent), point two (the pre-treatment effluent) and point three (treated effluent). Polyethylene bottles already washed with dilute mineral acid solution and rinsed with demineralized water were used to collect the samples. Sampling containers were rinsed two to three times with the samples to be collected. Grab type sampling technique was used. Collected samples were analyzed for the parameters $\mathrm{pH}$, temperature, Electrical Conductivity (EC), Dissolved Oxygen (DO), Total Dissolved Solids (TDS), Phosphate $\left(\mathrm{PO}_{4}{ }^{3-}\right)$ Chloride $\left(\mathrm{Cl}^{-}\right)$, Iron $(\mathrm{Fe})$ and Chromium $(\mathrm{Cr})$. Samples were taken to the laboratory on the same day of sampling to determine various parameters according to standard methods for examining waste water.

Biotec in Brazil installed the wastewater treatment plant. Wastewater treatment will start with pretreatment in a special channel where solids and coarse substance (coarse solids, sand and soil, fats and oil are removed. Bars screen (grit separator) are installed at the reception channel to remove materials. This then is followed up in the calamity tank where waste waters with moderate or high toxicity or high concentration such as caustic soda or hazardous characteristics are removed. Next in the treatment process is the entry of wastewater into the buffer tank where anaerobic process starts. Eventually the aeration basin mixed liquor flows by gravity into the final clarifier where the treated wastewater and sludge are separated. The bottom of the clarifier is tronc-conic to facilitate the sludge removal from it. Part of the settled activated sludge is returned to the aeration tank to maintain a minimum amount of active biomass.

Three samples a day were collected from the three locations or points for five consecutive days resulting in fifteen (15) samples collected during the study period. In situ measurements were made for $\mathrm{pH}$, temperature, electrical conductivity, total dissolved solids and dissolved oxygen using the appropriate probes in the field. Samples not analyzed in the field were immediately taken to the Sierra Leone Water Company (SALWACO) for chemical analyses. The chemical analysis was conducted by Spectrophotometric Method using the HACH DR/2800 Spectrophotometer. Laboratory analytical procedures were in accordance with procedures outlined in the HACH Water Analysis Handbook, $4^{\text {th }}$ Edition. All devices and equipment used were kept in the laboratory and reference materials necessary were of analytical grade. Calibration procedures for all tests were in accordance with the reference manual for each indicator. Efficiency was calculated in accordance with the literature [8, 9].

\section{Removal Efficiency \\ Influent Concentration - Effluent Concentration Influent Concentration}

\section{Results and Discussion}

The week long survey revealed that all of the samples collected at the influent point showed that higher $\mathrm{pH}$ values were outside guideline standards (5.5-9.0) for influents, but 
those collected at the effluent point were all within the guideline standards. All the influent and effluents samples for EC were higher than the permissible levels $(150 \mu \mathrm{S} / \mathrm{cm})$ as reported by [8]. $80 \%$ of the samples at the influent point were within guideline standards of $(2100 \mathrm{ppm})$ for TDS but all were in total agreement with the effluent samples for the same parameter. $20 \%$ of the influent samples collected for $\mathrm{Cl}^{-}$ were higher than the guideline standard $(600 \mathrm{mg} / \mathrm{L})$ but all of the samples collected at the effluent point conform fully to the agreed standard for the same parameter. Effluent temperatures and phosphate levels at both the influent and effluent sampling points were in good agreement with the guideline standards $\left(45^{\circ} \mathrm{C}\right.$ and $\left.5 \mathrm{mg} / \mathrm{L}\right)$, respectively. Similarly, samples for both iron and chromium collected at the influent and effluent points were in conformity with the guideline standards ( $3 \mathrm{mg} / \mathrm{L}$ and $2 \mathrm{mg} / \mathrm{L})$, respectively.

The results for nine parameters associated with effluents discharge is presented in Figure 1. It could be observed that influent and pretreatment effluents for $\mathrm{pH}$, temperature and iron, do not show meaningful differences. However, samples collected at the influent and pretreatment containments showed considerable differences in the values for conductivity, total dissolved solids, dissolved oxygen, phosphate, chloride and chromium as revealed in Figure 1.
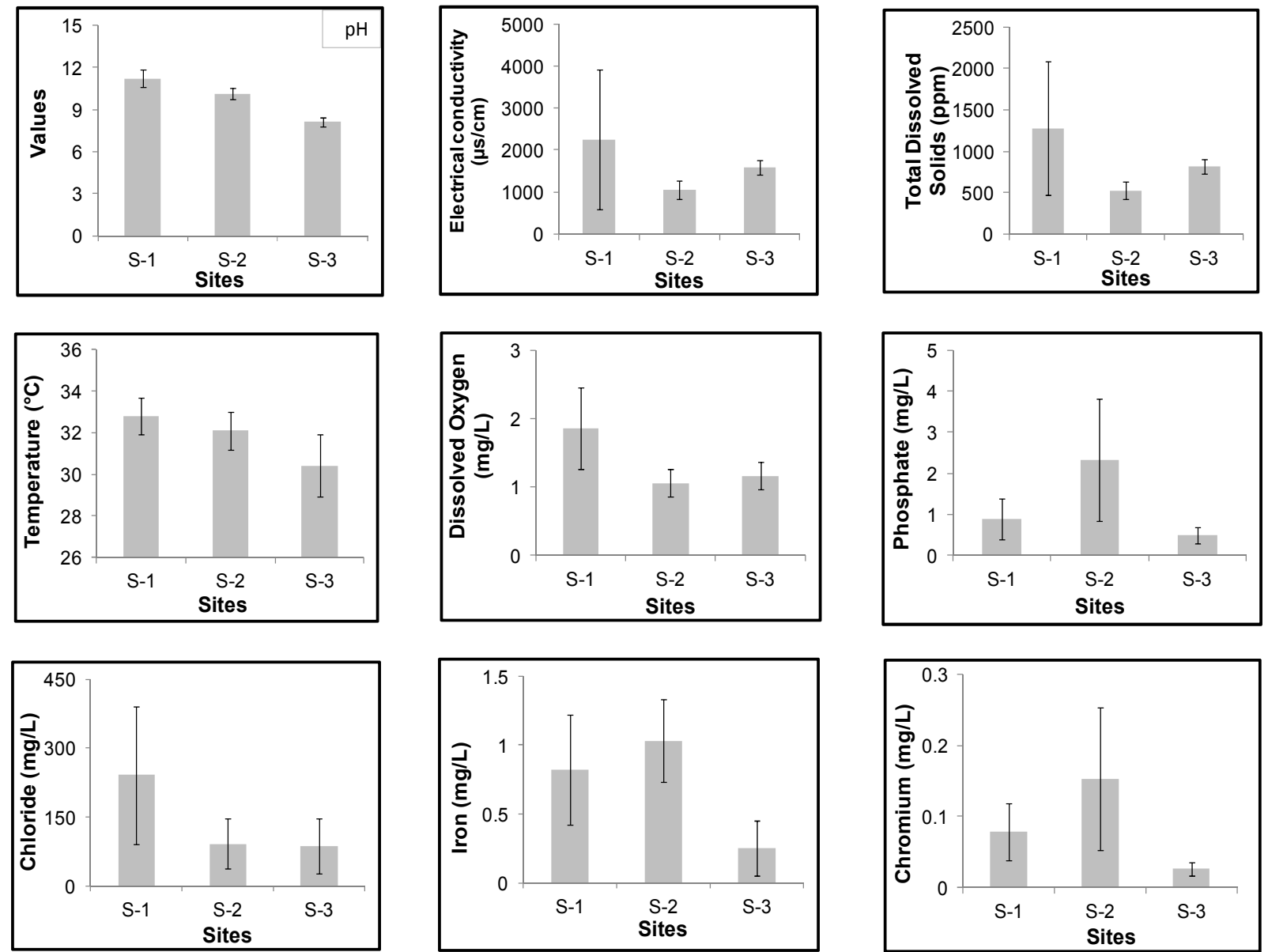

Figure 1. Showing results for influents, pre-treatment effluents and effluents concentrations. S-1 denotes influent concentration site; S-2 denote pretreatment concentration site and $S-3$ denotes effluent concentration site.

Table 1 presented comparison between influent and effluent concentrations. From Table 1, there was significant reduction in values of $\mathrm{pH}$, temperature, iron and chromium in the effluent samples relative to the influent samples. All other parameters did not show any statistically significant differences between the two points.

Table 1. Comparison between influent concentrations and effluents concentrations for all the indicators studied.

\begin{tabular}{llll}
\hline No & Indicators (Units) & Site 1 & Site 3 \\
\hline 1 & $\mathrm{pH}$ & $11.2 \pm 0.6$ & $8.1 \pm 0.3$ \\
2 & Conductivity $(\mu \mathrm{S} / \mathrm{cm})$ & $2252.1 \pm 1665.9$ & $1582 \pm 165.7$ \\
3 & Total Dissolved Solids $(\mathrm{mg} / \mathrm{L})$ & $1278.8 \pm 805.5$ & $816.4 \pm 83.2$ \\
4 & Temperature $\left({ }^{\circ} \mathrm{C}\right)$ & $32.8 \pm 0.9$ & $30.4 \pm 1.5$ \\
5 & Dissolved Oxygen $(\mathrm{mg} / \mathrm{L})$ & $1.9 \pm 0.6$ & 0.160 \\
6 & Phosphate $(\mathrm{mg} / \mathrm{L})$ & $0.9 \pm 1.1$ & 0.089 \\
7 & Chloride $(\mathrm{mg} / \mathrm{L})$ & $242.3 \pm 415.0$ & 0.003 \\
8 & Iron $(\mathrm{mg} / \mathrm{L})$ & $0.8 \pm 0.4$ & 0.016 \\
9 & Chromium $(\mathrm{mg} / \mathrm{L})$ & $0.08 \pm 0.04$ & 0.215 \\
\hline
\end{tabular}


Figure 2 showed the removal efficiency of contaminants before being released into the environment. The treatment plant is noted to be highly efficient in removing iron and least efficient for water temperature as reflected in Figure 2. Huge variances for chloride, electrical conductivity and total dissolved solids were noted according to Figure 2.

The $\mathrm{pH}$ value in this study at the influent point pointed to alkalinity which could be strongly attributed to carbonated $\left(\mathrm{CO}_{3}{ }^{2-}\right)$ content that must have been used in fizzing mineral drinks. The $\mathrm{pH}$ level at the effluent point appeared in the range of neutrality. Results for $\mathrm{pH}$ in this study is in contrast with previous studies that have investigated effluent compositions even though there are variation in the study design and processes investigated $[5,8,12]$ but in line with a waste treatment plant in a municipality in Thailand [9]. Lower $\mathrm{pH}$ values have been reported to precipitate heavy metals $[8,13]$ and our observed values at the effluent point are in line with breakdown organic materials by bacteria into inorganic substances.

The amount of cation or anions in water could describe the conductiveness of that solution and is mostly measured by the conductivity. The significance of EC of water is its measure of salinity which greatly affects its taste with implication to water potability and irrigation purposes. Both the influent and effluent concentrations were significantly higher than the effluent discharge limit of $150 \mathrm{mS} / \mathrm{cm}$ although the influent concentrations are relative higher than the effluent concentrations. Even though our results for both the influent and effluent points are relatively lower than few sites that reported EC in Uganda [14], but there was one site which revealed high levels of EC in the same Ugandan study. Nevertheless, our results are far higher than what was reported in South Africa [8]. It should be noted that food and beverage industries release effluents with high levels of EC largely due a combination of sweeteners, dissolved minerals serving as additives or preservatives etc, added to the production process and the ultimate cleaning process after production. All of these processes may eventually find their ways into the water stream which are considered effluents in this study. TDS is a measure of the amount of dissolved minerals that influences the usability of water. TDS was found to be significantly reduced in the effluent concentrations at $90 \%$ significance level. We presumed that cationic minerals were probably present in the wastewater even though these ions were not measured.

Though a significant reduction in the mean temperature was noted for the effluent point, our results are lower than the values recorded for effluents released in a pharmaceutical industry in Nigeria [6] but are well within the permissible for wastewater discharge. High temperatures in industrial effluents reduce solubility of oxygen and amplify odor due to anaerobic reaction and could further affect the amount of dissolved oxygen in water. Results for DO in the current study showed a significant reduction in values relative to the permissible level of $5 \mathrm{mg} / \mathrm{L}$. Effluent concentrations was considerably reduced relative to the influent concentrations which could partly be attributed to the temperature driven process(es) of the wastewater treatment plant. Our results for DO are much lower than a previous study in Malawi [15], and we share similar sentiment that pollution load released from some of the industrial processes were high oxygen demanding waste containing organic matter and we share similar viewpoints with those reported earlier for wastewater treatment in Nepal [12] and that in Gaborone for indicators in industrial effluents [7]. For instance, the syrup room represents a potential of $50 \%$ of all BODs discharged and is due to the concentration of sugar in the syrup which may be relatively high in the liquid volume but this is transformed into by products in the buffer tank. There was a significant reduction in concentrations of effluent wastewater of iron and chromium relative to the influent concentrations were observed, and our results are in line with a previous study on beverage industry in wastewater composition in Pakistan which could have been due to treatment process [1].

The overall removal efficiency for each indicator was calculated and proportions and deviations are presented in Figure 2. The following pattern of $\mathrm{Fe}>\mathrm{Cr}>\mathrm{Cl}>\mathrm{PO} 4>\mathrm{DO}>\mathrm{EC}>\mathrm{pH}>\mathrm{TDS}>\mathrm{Temp}$ was observed indicating that the wastewater treatment plant of SLBC was highly efficient to remove trace metals before released into the environment. Removal efficiency of TDS was in agreement with a previous study [12]. Even though $\mathrm{Fe}$ and $\mathrm{Cr}$ were the two highly removed contaminants in the effluents of this study, previous studies have shown significant reduction in removal efficiency of less than $40 \%$ in South Africa [8, 11]. In the same study, the removal efficiency for $\mathrm{PO}_{4}{ }^{3-}$ is comparable with what we have reported. Difference in removal efficiency of contaminants in industrial effluents could be partly due to the treatment processes involved, varied composition of industrial effluents due to manufacturing procedures, age of the treatment plant etc.

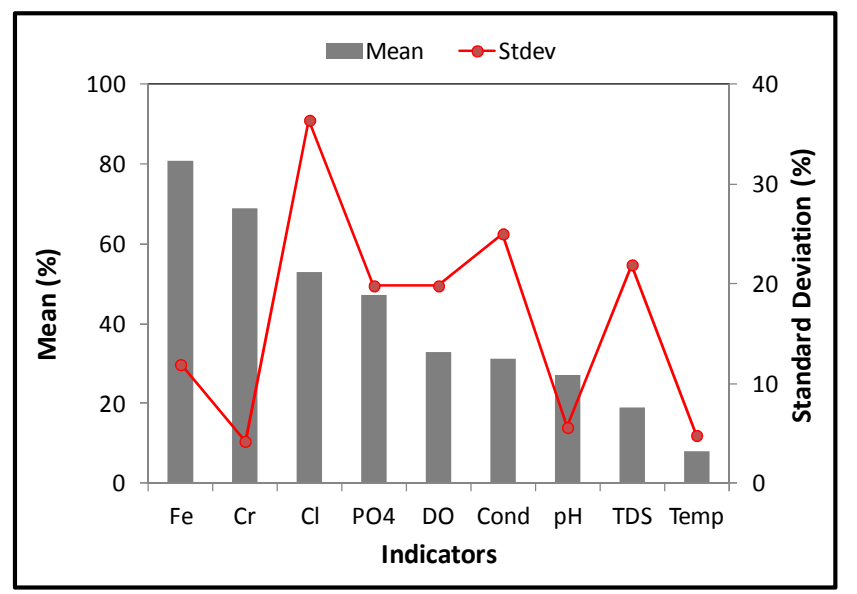

Figure 2. Removal efficiency reported in proportion for indicators investigated.

The SLBC requires huge volume of fresh water to drive its production and washing processes and ultimately discharges considerable amount of polluted wastewater considering the 
fact SLBC does not recycle its wastewater to reduce discharge into nearby streams. It was earlier reported that a beverage industry would require $3-4$ liters to produce $250 \mathrm{ml}$ $300 \mathrm{ml}$ of mineral drink [1]. In general, the performance of wastewater treatment plant depends on the type of macrophyte used, system configuration, pollutant loading and temperature. Considering the pollution load of certain parameters being investigated in this study, it is imperative for the SLBC to initiate the process of setting up Waste Stabilization Ponds (WSP) so as to contain industrial effluents for further examination before discharged into the environment. Although such proposed system is relatively cheap, land acquisition could be a main disadvantage considering this scarce resource around the vicinity of the company. Nonetheless, it was reported in Kenya that the removal efficiencies of certain parameters in wastewater were high [16] and this could serve as an incentive to improve the company's environmental performances.

\section{Conclusion}

This study has shown that release of effluents from SLBC into nearby streams and waterways are a source of contamination. High concentrations of electrical conductivity were observed although levels for almost all other indicators were within permissible limits of effluents standards. Absolute concentrations of the effluents were relatively lower than the influent concentrations and the removal efficiency of most contaminants are low with the exception of trace metals. Despite attempts have been made by SLBC to treat their wastewater, more treatment procedures are encouraged so as to increase the removal efficiencies of contaminants, and until then, such water is deemed unfit for irrigation and agricultural purposes.

\section{References}

[1] Haroon, H. Waseem A. Mahmood Q. Treatment and Reuse of Wastewater from Beverage Industry: Journal of Chemistry Society Pakistan 2013; 35: Pp: 5-10.

[2] Sarkar, B. Chakrabarti P. P. Vijaykumar A. Kale V. Wastewater treatment in dairy industries-possibility of reuse: Desalination 2006; 195: Pp: 141-152.

[3] Mekala, G. D. Davidson B. Samad M. Boland A. A. (2008): Framework for Efficient Wastewater Treatment and Recycling Systems; IWMI Working Paper 129; International Water Management Institute: Colombo, Sri Lanka. http://ageconsearch.umn.edu/bitstream/46387/2/WOR129.pdf (5th March, 2017).

[4] Muthukumaran, N. K A. N. Wastewater Treatment and Management in Urban Areas-A Case Study of Tiruchirappalli City, Tamil Nadu, India. In Proceedings of the Third International Conference on Environment and Health, Chennai, India: 2003; Pp: 284-289.
[5] Osho, A. Mabekoje O. O. Bello O. O. Preliminary evaluation of wastewater effluents from two food companies in Nigeria: African Journal of Microbiology Research 2010; 4: Pp: 13951399.

[6] Idris, M. A. Kolo B. G. Garba S. T. Ismail M. A. Physicochemical Analysis of Pharmaceutical Effluent and Surface Water of River Gorax in Minna, Niger State, Nigeria: Bulletin of Environment, Pharmacology and Life Sciences 2013; 2: Pp: 45-49.

[7] Emongor, V. Nkegbe E. Kealotswe B. Koorapetse I. Sankwasa S. Keikanetswe S. Pollution Indicators in Gaborone Industrial Effluent: Journal of Applied Sciences 2005; 5: Pp: 147-150.

[8] Edokpayi, J. N. Odiyo J. O. Msagati T. A. M. Popoola E. O. Removal Efficiency of Faecal Indicator Organisms, Nutrients and Heavy Metals from a Peri-Urban Wastewater Treatment Plant in Thohoyandou, Limpopo Province, South Africa: International Journal of Environmental Research and Public Health 2015; 12: Pp: 7300-7320.

[9] Kantachote, D. Kanthasorn Dangtago K. Siriwong C. Treatment efficiency in wastewater treatment plant of Hat Yai Municipality by quantitative removal of microbial indicators: Songklanakarin J. Sci. Technol 2009; 31: Pp: 567-576.

[10] Cavaco, S. A. Fernandes S. Quina M. M. Ferreira L. M. Removal of chromium from electroplating industry effluents by ion exchange resins: Journal of Hazardous Materials 2007; 144: Pp: 634-638.

[11] Olujimi, O. O. Fatoki O. S. Odendaal J. P. Daso A. P. Oputu O. U. Variation in levels and removal efficiency of heavy and trace metals from wastewater treatment plant effluents in Cape Town and Stellenbosch, South Africa: African Journal of Biotechnology 2016; 15: Pp: 1101-1135.

[12] Ravi Kumar, P. Liza Britta P. Somashekar R. K. ASSESSMENT OF THE EFFICIENCY OF SEWAGE TREATMENT PLANTS: A COMPARATIVE STUDY BETWEEN NAGASANDRA AND MAILASANDRA SEWAGE TREATMENT PLANTS: Kathmandu University Journal of Science, Engineering and Technology 2009; 6: Pp: 115-125.

[13] Barakat, M. A. New trends in removing heavy metals from industrial wastewater: Arabian Journal of Chemistry 2011; 4: Pp: 361-377.

[14] Walakira, P. Okot-Okumu J. Impact of Industrial Effluents on Water Quality of Streams in Nakawa-Ntinda, Uganda: Journal of Applied Sciences Environment and Management 2011; 15: Pp: $289-296$.

[15] Phiri, O. Mumba P. Moyo B. H. Z. Kadewa W. Assessment of the impact of industrial effluents on water quality of receiving rivers in urban areas of Malawi: International Journal of Environmental Science and Technology 2005; 2: Pp: 237-244.

[16] Mburu, N. Tebitendwa S. M. van Bruggen J. J. A. Rousseau D. P. L. Lens P. N. L. Performance Comparison and Economics Analysis ofWaste Stabilization Ponds and Horizontal Subsurface Flow ConstructedWetlands Treating Domestic Wastewater: A Case Study of the Juja Sewage Treatment Works: Journal of Environmental Management 2013; 128: Pp: 220-225. 